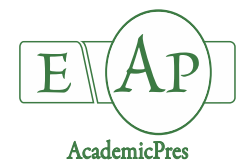

Farazmandi M et al. $(2020)$
Notulae Botanicae Horti Agrobotanici Cluj-Napoca 48(4):2279-2291
DOI:10.15835/48411790
Research Article

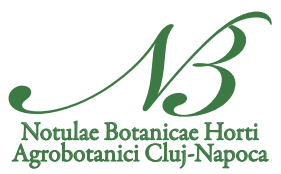

\title{
Physiological characteristics and vase life responses of rose cut flowers (Rosa hybrida L. cv. 'Royal Baccara') to benzyl adenine and 1- metylcylcopropene
}

\author{
Mojdeh FARAZMANDI ${ }^{1}$, Abbas MIRZAKHANI ${ }^{2 *}$, Nour A. SAJEDI ${ }^{3 *}$, \\ Mohammad NASRI ${ }^{4}$, Masoud GOMARIYAN ${ }^{3}$ \\ IDepartment of Horticulture, Arak Branch, Islamic Azad University, Arak, Iran; m.farazmandi@yahoo.com \\ ${ }^{2}$ Horticulture Crops Research Department, Markazi Agricultural and Natural Resources Research and Education Center, AREEO, \\ Arak,Iran;mirz51@yahoo.com (*corresponding author) \\ ${ }^{3}$ Department of Agronomy and Plant Breeding, Research Center of Applied Plant sciences, Arak Branch, Islamic Azad University, \\ Arak,Iran;N-sajedi@iau-arak.ac.ir;M-gomarian@iau-arak.ac.ir \\ ${ }^{4}$ Department of Agronomy, Varamin Branch, Islamic Azad University, Varamin - Pishva, Varamin, Tehran, Iran; \\ nasri@iauvarami.ac.ir
}

\begin{abstract}
+prolonging vase life and decreasing post-harvest losses are considered a basic strategy towards sustainable development of agriculture, and the application of growth regulators, e.g. benzyl adenine(BA) and 1-metylcylcopropane(1-MCP), is one of the practical methods for them. The effects of benzyl adenine(BA) and 1-metylcylcopropene(1-MCP) on some biochemical characteristics and vase life of rose cv. 'Royal Baccara' (Rosa hybrida L. cv. 'Royal Baccara'), were explored in a factorial experiment based on a randomized complete block design with three replications in 2017. The factors included BA at three levels of 0 (control), 75 and $150 \mathrm{ppm}$ and 1-MCP in three levels of 0 (control), 1 and $2 \mu \mathrm{l} / \mathrm{L}^{-1}$. The results showed that the maximum soluble protein content was observed in $150(\mathrm{ppm}) \mathrm{BA}+2\left(\mu \mathrm{l} . \mathrm{L}^{-1}\right) 1-\mathrm{MCP}$ treatments on the second, fourth, sixth, and eighth days. The results of this research revealed that BA at the rates of 75 and 150 ppm and 1-MCP at the rates of 1 and $2\left(\mu l . L^{-1}\right)$ enhanced soluble protein content by $10.49,13.37,15.18$, and 18.18 percent as compared to the control, respectively. The results showed that the maximum proline content was related to the control and the minimum content was observed in the plants treated with 150 (ppm) $\mathrm{BA}+2\left(\mu \mathrm{l} . \mathrm{L}^{-1}\right) 1-\mathrm{MCP}$. The endoproteases enzyme content was slightly decreased on the eighth day, indicating the efficacy of $\mathrm{BA}$ and $1-\mathrm{MCP}$ in inhibiting the senescence process and prolonging vase life of rose flowers. The results showed that the application of 1 or $2 \mu l . \mathrm{L}^{-1} 1-\mathrm{MCP}$ and $150 \mathrm{mg} \mathrm{L}^{-1} \mathrm{BA}$ can improve the vase life of cut roses
\end{abstract}

Keywords: endoproteases enzyme; growth regulator; proline content; rose flower 


\section{Introduction}

Rose,( Rosa hybrida L.), belongs to the important family of Rosaceae and is one of the most important cut flowers in the world so that, it presently has the first rank in terms of cultivation and trade in most countries of the world (Anonymous, 2016). In spite of their high economic value, cut flowers are highly prone to putrefaction. Due to their high rate of respiration and vulnerability, cut flowers need more attention in the postharvest stage (Kader, 2013). Flower senescence symptoms include wilting, abscission and discoloration of petals. These symptoms vary in different flowers. In rose cut flowers, petal wilting is accompanied by a decrease in water absorption, flower senescence, abscission and discoloration of petals. These symptoms vary in different flowers. These consequents indicate the inability of petals to absorb water, which results in flower senescence (Jin et al., 2016). Low water absorption and transpiration give rise to an increase in cut flower wastes (Hahn et al., 2011). Hence, the control of production conditions and the use of growth regulators and anti-stress compounds are very important for the quantitative and qualitative improvement of flowers (Yang and Kao, 2002). Nowadays the short vase life of cut flowers and leaves is one of the most important problems of their production (Van Meeteren et al., 2015). It is important to use methods that can prolong flowers vase life (Wagstaff et al., 2002).

Benzyl adenine (BA) and1-metylcylcopropene(1-MCP) are compounds that influence rose flowers postharvest life longevity (Huang et al., 2009). BA is considered a synthetic cytokinin. Cytokinins mainly affect cell division, thereby delaying senescence and shoot branching in ornamental plants (Iqbal et al., 2012). Due to its considerable effects on increasing crop quality, 1-MCP has recently been used to protect crops from the destructive effects of ethylene in different countries all around the world (Mutu, 2011). 1-MCP seemingly prevents ethylene bonding to its certain receptors in the plant and inhibits the expression of some regulator genes in maturation stages such as tACS2, tACS4 and tAco (Sisler et al., 2009). Researchers have attributed cytokinin effectiveness to the stimulation of calcium ion absorption in cell walls and demonstrated that certain cytokinins impact the induction of phosphoenolpyruvate carboxylase (the key enzyme in crassulacean acid metabolism, accumulation of proline, and PEPCase and carbonic dehydrogenase in plants) (Ranwala and Miller, 2000). Applying these compounds to plants decreases stress damage, improves solution absorption and maintains petals turgor pressure. Likewise BA reduces respiration rate, sensitivity to ethylene and hinders ethylene synthesis (Serek et al., 2014). The presence of cytokinins also delays protein degradation and cell death by inhibiting ribonuclease activity (Rao et al., 2012). Researchers have asserted that mechanisms by which BA growth regulator delays senescence in lily's fallen leaves are still unknown, but as the respiration rate was low in the leaves treated with BA, it can be said that it results in a rapid decrease in protein degradation. Therefore, BA supplies the deficiency in the required adenine for ribonucleic acid as such, it results in the molecule regeneration and consequently delays protein degradation (Ozden and Karaaslan, 2011). Proline accumulation is another biochemical index in flower senescence. In plants exposed to stress, proline content increases faster than other amino acids (Bates et al., 1973). Proline accumulation during leaf senescence has previously been reported in calla lily (Sahi, 2009) and rice (Yang and Kao, 2002) leaves. In a research conducted on the vase life of some cattleya orchid flowers, a combination of BA treatment with 1-MCP had some kind of exacerbating effect on the shelf life of Pink Villa cultivar. Therefore, $1-\mathrm{MCP}$, sucrose, and BA treatment were reported as the most effective ways for improving the viability of cattleya flowers (Ranwala and Miller, 2000). In a research, 1-MCP at a rate of $10 \mathrm{nl} . \mathrm{L}^{-1}$ resulted in an increase in vase life and a decrease in respiratory quotient in the stock cut flower(Darras et al., 2010). Similarly a positive effect of 1-MCP was reported on the postharvest quality of tulip cut flowers by lowering ethylene efficacy (Chutichudet et al., 2010). In flowers treated with 1-MCP, water absorption has always been more than the control as well; therefore, this factor can have a great impact on extending vase life, and it can be concluded that a decrease in water up take in rose flowers is associated with their vase life loss(Paull and Goo, 2005). This experiment was conducted to assess the effects of BA and 1-MCP on some physiological traits and vase life of roses cv. 'Baccara' 


\section{Materials and Methods}

\section{Experimental design}

To study the effects of BA and 1-MCP on the physiological characteristics, persistence, and vaselife of Rosa hybrida L. cv. 'Royal Bacara', a factorial experiment was conducted based on a randomized complete block design in 2017. The research was carried out with two factors including BA, the first factor at three levels of 0,75 , and $150 \mathrm{ppm}$, and 1-MCP at three rates of 0,1 , and $2\left(\mu 1 . \mathrm{L}^{-1}\right)$, in three replications on cut roses (Rosa hyblida L.) cv. 'Royal Bacara'. The cut flower postharvest treatments were accomplished as shortterm treatments (pulsing). The flowers were procured from a commercial greenhouse in Tehran province. One gram 1-MCP pills used in this research were made in the USA ${ }^{1}$, which were 0.127 percent pure according to claims of the manufacturing company. The cut flowers were put in the desired concentrations of 1-MCP for about 12 hours to assess the interaction of this compound with BA that was procured at Merck Germany Company. Distilled water (solution with no chemicals) was used as the control and all cut flowers were soaked in it. Then the cut flowers were placed in a standard control room at $22 \pm 1{ }^{\circ} \mathrm{C}$, under a light intensity of $15 \mu \mathrm{mol} \mathrm{m}{ }^{-2} \mathrm{~s}^{-1}$, with a relative humidity of 60 to $70 \%$ and lightness/darkness cycle of 12:12 hours. It should be mentioned that nine cut flowers were used in each treatment. The following traits were eventually measured.

\section{Vase life}

In all the treatments, the number of days after harvest up to the appearance of petals senescence symptoms (welting of two-thirds of the petals) were considered as the vase life (Liao et al., 2009).

\section{Solution uptake}

Preservative solution uptake was calculated by the following equation (Humaid, 2004):

$$
F W_{\mathrm{mL} \mathrm{day}}{ }^{-1} \mathrm{~g}^{-1}=\frac{S_{t-1}-S_{t}}{W_{t}}
$$

where $S t$ is the weight of vase solution (g) at $t=$ day $1,2,3$, etc., $\mathrm{St}^{-1}$ is the weight of vase solution $(\mathrm{g})$ on previous day and $\mathrm{W}_{\mathrm{t}}$ is the initial fresh weight.

\section{Biochemical traits}

The soluble protein content was measured as follows (Eason et al., 2002):

$$
\left(\mu g \mathrm{mg} \mathrm{FW} W^{-1}\right)=\left(X \mu g 50 \mu l^{-1}\right) \times\left(1000 \mu l 100 \mathrm{mg} \mathrm{FW}^{-1}\right)
$$

To measure the activity of endoproteases, the following optimized method was applied (Eason et al. 2002; Wagstaff et al., 2002):

$$
\begin{aligned}
& \left(\text { Endoproteases activity) } \triangle A 440 \text { (units } m g F W_{h-1}\right) \\
& \quad=\{A 440(\text { sample })-A 440(\text { blank })\} \times 0.0347
\end{aligned}
$$

The soluble carbohydrates concentration was measured by using the high performance liquid chromatography (Humaid, 2004; Ichimura et al., 2015). The proline content of petals was measured according to the method of Irigoyen et al. (1993).

\section{Ethylene measurement}

Ethylene was measured by the Gas chromatography method. For this purpose, each branch of the cut flowers was placed in a 2-liter impermeable bottle at $20^{\circ} \mathrm{C}$ and after $1 \mathrm{~h}$, it was sampled with a special syringe (about $1 \mathrm{ml}$ of bottle gases) and injected to the gas chromatography (GC) apparatus and the amount of ethylene was recorded.

1- Ethylbloc (Rohm-Haas, Spring House, PA), USA 


\section{Measurement of soluble carbohydrate concentration}

To measure the concentration of soluble carbohydrates, $1 \mathrm{~g}$ of petals and stems were harvested and their carbohydrates content in them were determined by high performance liquid chromatography (Humaid, 2004).

\section{Proline measurement}

Free proline content was determined according to the method described by Irigoyen et al., (1993) with slight modifications. A $2 \%$ homogenate of the fresh leaf was prepared with $3 \%$ aq. sulfosalicylic acid and centrifuged at $3500 \mathrm{rpm}$ at $4{ }^{\circ} \mathrm{C}$ for $15 \mathrm{~min}$. Two milliliter of supernatant was taken and $2 \mathrm{ml}$ of glacial acetic acid and acid ninhydrin reagent was added. The reaction mixture was boiled in water bath for $60 \mathrm{~min}$ and then cooled on ice. Then $4 \mathrm{ml}$ of toluene was added and incubated at room temperature for $30 \mathrm{~min}$. Tubes were then shaken for $15 \mathrm{sec}$ and allowed to stand for $10 \mathrm{~min}$ for phase separation. The upper phase was separated and absorbance was measured using spectrophotometer and the concentration of free proline was calculated using proline standard.

\section{Statistical analysis}

At the end of the experiment, the results of each treatment were analyzed in variance by the SAS software and the data means were compared at the levels of $1 \%$ and $5 \%$ using Duncan's multiple range test.

\section{Results and Discussion}

The effects of BA and 1-MCP on the physiological traits, persistence and viability of cut roses (Rosa hybrida L.) cv. 'Royal Baccara' were assessed on different days. The variance analysis table suggested that the soluble protein content, solution uptake, proline content, endoprotease enzymes, stem and petal carbohydrates and vase life were affected by the simple and interactive effects of BA and 1-MCP on different days, and the observed differences were statistically significant at one and five percent levels (Tables 1, 3, 5, 7 and 9).

\section{Soluble protein}

The results of the means comparison of the interactive effects demonstrated that the maximum soluble protein content was observed in the plants treated with $150(\mathrm{ppm}) \mathrm{BA}+2\left(\mu \mathrm{l} . \mathrm{L}^{-1}\right) 1-\mathrm{MCP}$ on the second, fourth, sixth, and eighth days, which statistically had no significant difference with those treated with 150 (ppm) BA +1 $\left(\mu \mathrm{l} . \mathrm{L}^{-1}\right) 1-\mathrm{MCP}, 75(\mathrm{ppm}) \mathrm{BA}+2\left(\mu \mathrm{l} . \mathrm{L}^{-1}\right) 1-\mathrm{MCP}$, and $150(\mathrm{ppm}) \mathrm{BA}$. The minimum soluble protein was observed in the control treatment (Table 2). Cytokinins delay senescence by preventing protein and chlorophyll degradation and BA supplies the deficiency of adenine required for ribonucleic acid, thereby regenerating molecules and delaying degradation of proteins (Mutu, 2011). Cytokinins are found as one of the alkalis adjacent to anticodon in some transfer RNAs, so they might be responsible for binding transfer RNA to ribosomes during protein generation (Yamada et al., 2012). The results revealed that BA at the rates of 75 and $150 \mathrm{ppm}$ and 1-MCP at the rates of 1 and 2 $\left(\mu \mathrm{l} . \mathrm{L}^{-1}\right)$ enhanced soluble protein content by $10.49,13.37,15.18$, and 18.18 percent, respectively, as compared to the control. The interaction of anti-aging substances could generate the maximum soluble protein content, increase the intracellular macromolecules, prevent ion leakage and cell wall degradation, reduce water absorption, and result in senescence. From the eighth day onwards, the water absorption rate and soluble protein content started to diminish in all treatments compared to the sixth, fourth days and it seems that with the onset of the senescence process, the main metabolites are transferred from the aged organs into the plant and consumed for the growth of other organs. This is consistent with the results of other studies (Buchanan-Wollaston, 2015). 
Table 1. Analysis of variance of soluble protein affected by BA and 1- MCP

\begin{tabular}{|c|c|c|c|c|c|}
\hline & & & M.s & & Day8 \\
\hline S.O.V & df & Day2 & Day4 & Day6 & $0.082^{*}$ \\
\hline BA & 2 & $0.045^{*}$ & $0.42^{*}$ & $0.071^{*}$ & $0.031^{\text {ns }}$ \\
\hline $1-M C P$ & 2 & $0.039^{*}$ & $20.81^{* *}$ & $0.065^{*}$ & $125.401^{*}$ \\
\hline $1-M C P \times B A$ & 4 & $29.42^{* *}$ & $51.43^{* *}$ & $42.4^{* *}$ & 0.015 \\
\hline Error & 27 & 0.005 & 0.061 & 0.009 & 7.14 \\
\hline CV & - & 5.81 & 6.28 & 7.21 & \\
\hline
\end{tabular}

ns," and "represent non-significant and significant at the $1 \%$ and $5 \%$ probability levels, respectively.

Table 2. Comparison of the interactive effects of BA and 1- MCP on soluble protein

\begin{tabular}{|c|c|c|c|c|}
\hline & \multicolumn{4}{|c|}{ (Soluble protein mg/fw) } \\
\hline Treatment & Day 2 & Day 4 & Day 6 & Day 8 \\
\hline Control & $1.73 \mathrm{e}$ & $1.72 \mathrm{~d}$ & $1.69 \mathrm{~d}$ & $1.62 \mathrm{c}$ \\
\hline $1 \mu \mathrm{l} / \mathrm{L} 1-\mathrm{MCP}$ & $1.93 \mathrm{~d}$ & $1.86 \mathrm{~cd}$ & $1.83 \mathrm{c}$ & $1.74 \mathrm{bc}$ \\
\hline $2 \mu \mathrm{l} / \mathrm{L} 1-\mathrm{MCP}$ & $2.14 \mathrm{bc}$ & $2.05 \mathrm{bc}$ & $1.92 \mathrm{abc}$ & $1.82 \mathrm{~b}$ \\
\hline $75 \mathrm{ppm} \mathrm{BA}$ & $2.07 \mathrm{~cd}$ & $1.92 \mathrm{bcd}$ & $1.84 \mathrm{c}$ & $1.78 \mathrm{~b}$ \\
\hline $1 \mu \mathrm{l} / \mathrm{L} 1-\mathrm{MCP} \times 75 \mathrm{ppm} \mathrm{BA}$ & $2.12 \mathrm{c}$ & $1.99 \mathrm{bc}$ & $1.88 \mathrm{bc}$ & $1.81 \mathrm{~b}$ \\
\hline $2 \mu \mathrm{l} / \mathrm{L} 1-\mathrm{MCP} \times 75 \mathrm{ppm} \mathrm{BA}$ & $2.28 \mathrm{ab}$ & $2.12 \mathrm{ab}$ & $1.96 \mathrm{ab}$ & $1.87 \mathrm{ab}$ \\
\hline $150 \mathrm{ppm} \mathrm{BA}$ & $2.15 \mathrm{bc}$ & $1.96 \mathrm{c}$ & $1.95 \mathrm{ab}$ & $1.84 \mathrm{ab}$ \\
\hline $1 \mu \mathrm{l} / \mathrm{L} 1-\mathrm{MCP} \times 150 \mathrm{ppm} \mathrm{BA}$ & $2.23 \mathrm{abc}$ & $2.08 \mathrm{~b}$ & $1.97 \mathrm{ab}$ & $1.91^{\mathrm{a}}$ \\
\hline $2 \mu \mathrm{l} / \mathrm{L} 1-\mathrm{MCP} \times 150 \mathrm{ppm} \mathrm{BA}$ & ${ }^{2} 2.34 \mathrm{a}$ & $2.24 \mathrm{a}$ & $2.09 \mathrm{a}$ & $1.98 \mathrm{a}$ \\
\hline
\end{tabular}

Numbers followed by the same letters are not significantly different $(\mathrm{P}<0.05)$.

\section{Solution uptake}

The results showed that the minimum amount of the absorbed solution was in the control treatment and the maximum was in the $150(\mathrm{ppm}) \mathrm{BA}+2\left(\mu \mathrm{l} \cdot \mathrm{L}^{-1}\right) 1-\mathrm{MCP}$ treatment on the second, fourth, sixth, and eighth days, which had no significant difference with the treatment of $150(\mathrm{ppm}) \mathrm{BA}+2\left(\mu \mathrm{l} \cdot \mathrm{L}^{-1}\right) 1-\mathrm{MCP}$ and so that all were placed in the same statistical group (Table 4). Although BA and 1-MCP reduced the petal aging trend to a great extent, the amount of solution uptake was remarkably decreased on the eighth day, which is the onset of the cell aging process. This amount was even lower than the absorbed solution on the first day (Table 4). The flowers treated with 1-MCP took up more water than the control (Paull and Goo, 2005). The results suggested that the value of $1.35\left(\mathrm{ml} \mathrm{gr}^{-1} . \mathrm{FW}^{-1}\right)$ in the control rose to $2.09\left(\mathrm{ml} \mathrm{gr}^{-1} . \mathrm{FW}^{-1}\right)$ which is a 35 percent increase. This value rose to $3.13\left(\mathrm{ml} \mathrm{gr}^{-1} \cdot \mathrm{FW}^{-1}\right)$ on average in the flowers treated with $75(\mathrm{ppm}) \mathrm{BA}+2\left(\mu \mathrm{l} . \mathrm{L}^{-1}\right) 1-\mathrm{MCP}$, which revealed an increase of 57 percent. The increased water absorption induced by these compounds increases the growth of the cell wall, improves the structure of macromolecules, and inhibits the dimerization of proteins. By protecting the structure and increasing sugar content by respiratory and osmotic pressure regulations, the aging process delays, so this factor might have a significant influence on the vase life prolongation. The results revealed that the decline in water uptake in the rose flowers was associated with the decreased vase life (Ichimura et al., 2015), which is quite evident in this experiment.

Table 3. Analysis of variance of solution uptake as affected by BA and 1- MCP

\begin{tabular}{|c|c|c|c|c|c|}
\hline & & & M.s & & \\
\hline S.O.V & $\mathrm{df}$ & Day 2 & Day 4 & Day 6 & Day 8 \\
\hline $\mathrm{BA}$ & 2 & $6257.4^{*}$ & $12463.6^{*}$ & $7159.2^{*}$ & $14591.3^{*}$ \\
\hline 1-MCP & 2 & $2810.3^{\text {ns }}$ & $14093.2^{*}$ & $7024.9^{*}$ & $72985.4^{*}$ \\
\hline 1-MCP $\times \mathrm{BA}$ & 4 & $7659.1^{*}$ & $13802.7^{*}$ & $6526.4^{*}$ & $58482.1^{* *}$ \\
\hline Error & 27 & 1482.2 & 1987.4 & 998.1 & 2218.3 \\
\hline $\mathrm{CV}$ & - & 8.43 & 7.12 & 8.01 & 8.27 \\
\hline
\end{tabular}

ns, " and "represent non-significant and significant at the $1 \%$ and $5 \%$ probability levels, respectively. 
Table 4. Comparison of effects of interactions between $\mathrm{AB}$ and 1- MCP on absorbed solution

\begin{tabular}{|c|c|c|c|c|}
\hline & \multicolumn{4}{|c|}{ Absorbed solution (ml/gr.FW) } \\
\hline Treatments & Day 2 & Day 4 & Day 6 & Day 8 \\
\hline Control & $1.36 \mathrm{a}$ & $1.41 \mathrm{~d}$ & $1.47 \mathrm{c}$ & $1.35 \mathrm{~d}$ \\
\hline $1 \mu \mathrm{l} / \mathrm{L} 1-\mathrm{MCP}$ & $1.68 \mathrm{~cd}$ & $1.74 \mathrm{~d}$ & $1.81 \mathrm{c}$ & $1.62 \mathrm{~cd}$ \\
\hline $2 \mu \mathrm{l} / \mathrm{L} 1-\mathrm{MCP}$ & $1.91 \mathrm{~cd}$ & $2.16 \mathrm{~cd}$ & $2.27 \mathrm{bc}$ & $2.09 \mathrm{c}$ \\
\hline $75 \mathrm{ppm} \mathrm{BA}$ & $2.08 \mathrm{c}$ & $2.23 \mathrm{~cd}$ & $2.38 \mathrm{bc}$ & $2.11 \mathrm{c}$ \\
\hline $1 \mu \mathrm{l} / \mathrm{L} 1-\mathrm{MCP} \times 75 p p m$ BA & $2.46 \mathrm{bc}$ & $2.78 \mathrm{bc}$ & $2.91 \mathrm{~b}$ & $2.64 \mathrm{bc}$ \\
\hline $2 \mu \mathrm{l} / \mathrm{L} 1-\mathrm{MCP} \times 75 p p m$ BA & $2.89 \mathrm{~b}$ & $3.26 \mathrm{abc}$ & $3.47 \mathrm{ab}$ & $3.13 \mathrm{abc}$ \\
\hline $150 \mathrm{ppm} \mathrm{BA}$ & $2.57 \mathrm{bc}$ & $2.71 \mathrm{c}$ & $2.83 \mathrm{ab}$ & $2.67 \mathrm{bc}$ \\
\hline $1 \mu \mathrm{l} / \mathrm{L} 1-\mathrm{MCP} \times 150 \mathrm{ppm} \mathrm{BA}$ & $3.06 \mathrm{ab}$ & $3.38 \mathrm{ab}$ & $3.56 \mathrm{a}$ & $3.28 \mathrm{ab}$ \\
\hline $2 \mu \mathrm{l} / \mathrm{L} 1-\mathrm{MCP} \times 150 \mathrm{ppm} \mathrm{BA}$ & $3.64 \mathrm{a}$ & $3.94 \mathrm{a}$ & $4.07 \mathrm{a}$ & $3.86 \mathrm{a}$ \\
\hline
\end{tabular}

Numbers followed by the same letter $(s)$ are not significantly different $(\mathrm{P}<0.05)$.

\section{Proline content}

The results of the means comparison for the interactive effects suggested that the maximum proline content was in the control treatment and the minimum content was observed in $150(\mathrm{ppm}) \mathrm{BA}+2\left(\mu \mathrm{l} . \mathrm{L}^{-1}\right) 1-$ MCP treatment, on the second, fourth, sixth, and eighth days (Table 6). Although BA and 1-MCP reduced the petal aging trend to a great extent, proline content was considerably increased on the eighth day by 11 percent versus the second day, which indicates an improvement in cell resistance to environmental stimulants (Table 6). Plants enhance their resistance against senescence through the accumulation of osmotic regulator materials, e.g. proline, amino acids and soluble carbohydrates (Ashraf and Foolad, 2007). Researchers have attributed cytokinin effectiveness to the stimulation of calcium ion absorption in cell walls and demonstrated that certain cytokinins are effective in inducing phosphoenolpyruvate carboxylase [the key enzyme in crassulacean acid metabolism (CAM)] metabolism, proline accumulation, and PEPCase and carbonic dehydrogenase in plants (Rao et al., 2012). Recent studies have revealed that the treatment of iris flowers with1-MCP restrained petal proteins from degradation and delayed senescence. Proline accumulation in leaves at the senescence stage has been reported in calla lily while in rose flowers, increase in proline has been only reported at aging petals (Kumar et al., 2008). The results of this experiment suggested that proline content was increased by 10 percent in the control treatment from the second to eighth experimental days from $1.186(\mu \mathrm{mol} / \mathrm{g} . \mathrm{FW})$ to $1.324(\mu \mathrm{mol} / \mathrm{g}$.FW), but with the application of BA and 1-MCP, it was increased from $0.887(\mu \mathrm{mol} / \mathrm{g}$.FW) on the second day to $0.958(\mu \mathrm{mol} / \mathrm{g}$.FW) on the eighth day, implying only 7 percent increase. Therefore, the simultaneous application of $\mathrm{BA}$ and 1-MCP reduced ethylene production and increased $\mathrm{O}^{-2}$ and $\mathrm{H}_{2} \mathrm{O}_{2}$ breakdown and inhibited the synthesis of cellular free radicals (Macnish et al., 2010). By changing ethylene receptor bands (Sisler et al., 2009) induced a competitive increase in the freshness duration of the petal. In fact, by declining protein degradation(Darras et al., 2010) the proline content was decreased and BA brought about molecule regeneration by supplying the required adenine for ribonucleic acid (Mutu, 2011), so the proline increase rate was lessened which is evident in the present research.

Table 5. Analysis of variance of proline content under BA and 1- MCP

\begin{tabular}{|c|c|c|c|c|c|}
\hline & & & M.s & & \\
\hline S.O.V & $\mathrm{df}$ & Day2 & Day4 & Day6 & Day8 \\
\hline BA & 2 & $0.0211^{*}$ & $0.082^{*}$ & $6.138^{*}$ & $125.012^{* *}$ \\
\hline 1-MCP & 2 & $0.0193^{*}$ & $0.078^{*}$ & $6.457^{*}$ & $78.429^{* *}$ \\
\hline $1-\mathrm{MCP} \times \mathrm{BA}$ & 4 & $0.285^{*}$ & $22.49^{* *}$ & $33.452^{* *}$ & $491.387^{* *}$ \\
\hline Error & 27 & 0.0031 & 0.012 & 0.98 & 0.0105 \\
\hline $\mathrm{CV}$ & - & 4.51 & 5.28 & 3.92 & 4.23 \\
\hline
\end{tabular}

ns, ${ }^{* *}$ and ${ }^{*}$ represent non-significant and significant at the $1 \%$ and $5 \%$ probability levels, respectively. 
Table 6. Comparison of the interactive effects of $\mathrm{AB}$ and 1- MCP on proline

\begin{tabular}{|c|c|c|c|c|}
\hline & \multicolumn{4}{|c|}{ Proline $(\mu \mathrm{mol} / \mathrm{g}$. FW $)$} \\
\hline Treatments & Day 2 & Day 4 & Day 6 & Day 8 \\
\hline Control & $1.104 \mathrm{~b}$ & $1.116 \mathrm{ab}$ & $1.127 \mathrm{c}$ & $1.216 \mathrm{abc}$ \\
\hline $1 \mu \mathrm{l} / \mathrm{L} 1-\mathrm{MCP}$ & $0.979 \mathrm{~cd}$ & $1.025 \mathrm{~b}$ & $1.041 \mathrm{bc}$ & $1.096 \mathrm{bc}$ \\
\hline $2 \mu \mathrm{l} / \mathrm{L} 1-\mathrm{MCP}$ & $1.027 \mathrm{c}$ & $1.064 \mathrm{ab}$ & $1.081 \mathrm{bc}$ & $1.122 \mathrm{ab}$ \\
\hline $75 \mathrm{ppm} \mathrm{BA}$ & $0.937 \mathrm{de}$ & $0.982 \mathrm{bc}$ & $0.993 \mathrm{c}$ & $1.036 \mathrm{c}$ \\
\hline $1 \mu \mathrm{l} / \mathrm{L} 1-\mathrm{MCP} \times 75 \mathrm{ppm} \mathrm{BA}$ & $0.902 \mathrm{de}$ & $0.968 \mathrm{bc}$ & $0.976 \mathrm{~cd}$ & $0.983 \mathrm{~cd}$ \\
\hline $2 \mu \mathrm{l} / \mathrm{L} 1-\mathrm{MCP} \times 75 \mathrm{ppm} \mathrm{BA}$ & $0.949 \mathrm{~d}$ & $0.974 \mathrm{bc}$ & $0.986 \mathrm{~cd}$ & $1.072 \mathrm{bc}$ \\
\hline $150 \mathrm{ppm} \mathrm{BA}$ & $0.916 \mathrm{de}$ & $0.953 \mathrm{bc}$ & $0.968 \mathrm{~cd}$ & $0.986 \mathrm{~cd}$ \\
\hline $1 \mu \mathrm{l} / \mathrm{L} 1-\mathrm{MCP} \times 150 \mathrm{ppm} \mathrm{BA}$ & $0.887 \mathrm{e}$ & $0.926 \mathrm{c}$ & $0.937 \mathrm{~d}$ & $0.958 \mathrm{~d}$ \\
\hline $2 \mu \mathrm{l} / \mathrm{L} 1-\mathrm{MCP} \times 150 \mathrm{ppm} \mathrm{BA}$ & $1.104 \mathrm{~b}$ & $1.116 \mathrm{ab}$ & $1.127 \mathrm{c}$ & $1.216 \mathrm{abc}$ \\
\hline
\end{tabular}

Numbers followed by the same letter $(s)$ are not significantly different $(\mathrm{P}<0.05)$.

\section{Endoproteases enzyme}

The results suggested that the maximum endoproteases enzyme content was observed in the control treatment on the second, fourth, sixth, and eighth days, which statistically had no significant difference with all applied levels of 150 (ppm) BA and 1-MCP. The minimum endoproteases enzyme content was seen in $150(\mathrm{ppm}) \mathrm{BA}+2$ ( $\mu \mathrm{l} . \mathrm{L}) 1-\mathrm{MCP}$ treatment (Table 8). The endoproteases enzyme content was slightly decreased on the eighth day, indicating the efficacy of BA and 1-MCP in inhibiting the senescence process and increasing rose flower viability and vase life. However, the rise of endoproteases enzyme content was not remarkable on the eighth day. BA increased the postharvest longevity of rose flower by reducing endoproteases activity along with water absorption and following that, through inhibiting protein degradation. The endoproteases activity increase during the postharvest period was reported in alstroemeria and sandersonia flowers (Wagstaff et al., 2002) and it was shown that BA concentration in sandersonia flower resulted in increase of its postharvest life time and 4 days after treatment with 1-MCP, the endoproteases activity was delayed (Eason et al., 2002). The study of the observed biochemical changes by the BA treatment demonstrated that the activity of protease associated with petals gain, delayed, and therefore, the vase life enhanced. It seems that in this research BA contributed to the prolongation of flower longevity by lessening protease activity, which is consistent with other researchers' results (Eason et al., 2002). The results indicated that the simultaneous utilization of BA and1-MCP lowered the endoproteases activity by 35 percent on the eighth day, but the endoproteases activity of the control was increased by about 11 percent on the eighth day compared to the second day, which indicates the impact of BA and1-MCP on the senescence decline and the rise of vase life in this experiment.

Table 7. Analysis of variance of endoproteases under BA and 1- MCP

\begin{tabular}{|c|c|c|c|c|c|}
\hline & & & M.s & & \\
\hline S.O.V & df & Day2 & Day4 & Day6 & Day8 \\
\hline BA & 2 & $28.42^{\text {ns }}$ & $684.61^{*}$ & $403.42^{*}$ & $142.98^{*}$ \\
\hline $1-M C P$ & 2 & $32.37^{\text {ns }}$ & $371.27^{\text {ns }}$ & $84.02^{\text {ns }}$ & $31.29^{\text {ns }}$ \\
\hline $1-M C P \times B A$ & 4 & $219.42^{*}$ & $769.43^{*}$ & $351.22^{*}$ & $1985.27^{* *}$ \\
\hline Error & 27 & 29.27 & 102.48 & 49.54 & 20.81 \\
\hline CV & - & 8.45 & 7.12 & 7.46 & 7.02 \\
\hline
\end{tabular}

ns, ${ }^{* *}$ and ${ }^{*}$ represent non-significant and significant at the $1 \%$ and $5 \%$ probability levels, respectively. 
Table 8. Comparison of interactions between $\mathrm{AB}$ and 1- MCP for endoproteases

\begin{tabular}{|c|c|c|c|c|}
\hline & \multicolumn{3}{|c|}{ Endoproteases (u/h.mg.FW) } \\
\hline Treatments & Day 2 & Day 4 & Day 6 & Day 8 \\
\hline Control & $2.67 \mathrm{a}$ & $2.75 \mathrm{a}$ & $2.84 \mathrm{a}$ & $2.97 \mathrm{a}$ \\
\hline $1 \mu \mathrm{l} / \mathrm{L} 1-\mathrm{MCP}$ & $2.41 \mathrm{a}$ & $2.61 \mathrm{a}$ & $2.63 \mathrm{a}$ & $2.71 \mathrm{ab}$ \\
\hline $2 \mu \mathrm{l} / \mathrm{L} 1-\mathrm{MCP}$ & $2.35 \mathrm{ab}$ & $2.41 \mathrm{ab}$ & $2.51 \mathrm{ab}$ & $2.58 \mathrm{~b}$ \\
\hline $75 \mathrm{ppm} \mathrm{BA}$ & $2.31 \mathrm{ab}$ & $2.37 \mathrm{bc}$ & $2.39 \mathrm{abc}$ & $2.53 \mathrm{~b}$ \\
\hline $1 \mu \mathrm{l} / \mathrm{L} 1-\mathrm{MCP} \times 75 \mathrm{ppm} \mathrm{BA}$ & $2.16 \mathrm{ab}$ & $2.22 \mathrm{c}$ & $2.26 \mathrm{bc}$ & $2.41 \mathrm{bc}$ \\
\hline $2 \mu \mathrm{l} / \mathrm{L} 1-\mathrm{MCP} \times 75 p p m$ BA & $2.08 \mathrm{ab}$ & $2.16 \mathrm{~cd}$ & $2.19 \mathrm{bc}$ & $2.22 \mathrm{bc}$ \\
\hline $150 \mathrm{ppm} \mathrm{BA}$ & $2.20 \mathrm{ab}$ & $2.21 \mathrm{c}$ & $2.24 \mathrm{bc}$ & $2.32 \mathrm{bc}$ \\
\hline $1 \mu \mathrm{l} / \mathrm{L} 1-\mathrm{MCP} \times 150 \mathrm{ppm} \mathrm{BA}$ & $1.93 \mathrm{~b}$ & $1.93 \mathrm{~cd}$ & $2.04 \mathrm{bc}$ & $2.07 \mathrm{c}$ \\
\hline $2 \mu \mathrm{l} / \mathrm{L} 1-\mathrm{MCP} \times 150 \mathrm{ppm} \mathrm{BA}$ & $1.82 \mathrm{~b}$ & $1.82 \mathrm{~d}$ & $1.89 \mathrm{c}$ & $1.93 \mathrm{c}$ \\
\hline
\end{tabular}

Numbers followed by the same letter $(s)$ are not significantly different $(\mathrm{P}<0.05)$.

\section{Petal carbohydrate content}

The results of the means comparison for the interactive effects (Table 10) indicated that the maximum content of stem and petal soluble carbohydrates was obtained from 150 (ppm) BA+ 2 ( $\mu$ l.L)1-MCP treatment, on the second, fourth, sixth, and eighth days, which had no significant difference with the 150 (ppm) BA+ 1 ( $\mu$ l.L) 1-MCP treatment, so that both treatments were statistically the same. The minimum content of stem and petal soluble carbohydrates was seen in the control (Table 10). It seems that the respiration rate was low in the leaves treated with $\mathrm{BA}$ and therefore, it prevented the reduction of carbohydrates which is consistent with the results of Ranwala and Miller (2000). Carbohydrate content had an ascending trend from the second to the eighth day but with regard to the abovementioned points, it descended on the eighth day. This reduction was 7 percent in the control treatment and 3 percent in 150 $(\mathrm{ppm}) \mathrm{BA}+2$ ( $\mu \mathrm{l} . \mathrm{L}) 1-\mathrm{MCP}$ treatment. BA application resulted in the accumulation of structural carbohydrates in the flowers in normal conditions (Wang, 2009). BA application resulted in increased dissolved solids in petals and chlorophyll content, and by producing assimilates, enhanced the carbohydrate content. It should be mentioned that the clogging of stem xylems by unwanted microorganisms is one of the factors preventing its remobilization from the stem into the petals. 1-MCP prevented the growth of bacteria in the postharvest circumstance (Sood et al., 2006) and enhanced the stem water uptake ability, and the stem sugar content and intracellular water were increased by sucrose degradation (Mutu, 2011) which increased the rose flower vase life.

Table 9. Analysis of variance of soluble carbohydrate under BA and 1- MCP

\begin{tabular}{|c|c|c|c|c|c|}
\hline & & & M.s & & \\
\hline S.O.V & $\mathrm{df}$ & Day2 & Day4 & Day6 & Day8 \\
\hline BA & 2 & $687201.2^{*}$ & $287457.2^{*}$ & $151806.2^{* *}$ & $138217.2^{* *}$ \\
\hline $1-\mathrm{MCP}$ & 2 & 701452.6 & $332185.7^{*}$ & $69517.5^{*}$ & $13521.4^{*}$ \\
\hline $1-\mathrm{MCP} \times \mathrm{BA}$ & 4 & $1745321.8^{* *}$ & $2983001.6^{* *}$ & $852432.3^{* *}$ & $983297.7^{* *}$ \\
\hline Error & 27 & 98453.8 & 49413.7 & 10821.7 & 21502.6 \\
\hline CV & - & 7.82 & 8.29 & 8.48 & 8.96 \\
\hline
\end{tabular}

ns, ${ }^{* *}$ and ${ }^{*}$ represent non-significant and significant at the $1 \%$ and $5 \%$ probability levels, respectively. 
Table 10. Comparison of interactions between BA and 1- MCP on soluble carbohydrate

\begin{tabular}{|c|c|c|c|c|}
\hline & \multicolumn{4}{|c|}{ Soluble carbohydrate $(\mathrm{mg} / \mathrm{g})$} \\
\hline Treatments & Day 2 & Day 4 & Day 6 & Day 8 \\
\hline Control & $12.24 \mathrm{~d}^{\mathrm{d}}$ & $12.07 \mathrm{~d}$ & $12.38 \mathrm{~d}$ & $11.87 \mathrm{~d}$ \\
\hline $1 \mu \mathrm{l} / \mathrm{L} 1-\mathrm{MCP}$ & $13.07 \mathrm{~cd}$ & $12.63 \mathrm{~cd}$ & $13.17 \mathrm{~cd}$ & $12.04 \mathrm{~d}$ \\
\hline $2 \mu \mathrm{l} / \mathrm{L}$ 1-MCP & $13.51 \mathrm{~cd}$ & $13.24 \mathrm{~cd}$ & $13.88 \mathrm{bc}$ & $12.96 \mathrm{c}$ \\
\hline $75 \mathrm{ppm} \mathrm{BA}$ & $13.64 \mathrm{c}$ & $13.52 \mathrm{c}$ & $13.71 \mathrm{c}$ & $13.25 \mathrm{bc}$ \\
\hline $1 \mu \mathrm{l} / \mathrm{L} 1-\mathrm{MCP} \times 75 \mathrm{ppm} \mathrm{BA}$ & $13.98 \mathrm{bc}$ & $13.81 \mathrm{bc}$ & $14.13 \mathrm{bc}$ & $13.67 \mathrm{bc}$ \\
\hline $2 \mu \mathrm{l} / \mathrm{L} 1-\mathrm{MCP} \times 75 \mathrm{ppm} \mathrm{BA}$ & $14.46 \mathrm{bc}$ & $14.49 \mathrm{ab}$ & $14.86 \mathrm{bc}$ & $14.37 \mathrm{~b}$ \\
\hline $150 \mathrm{ppm} \mathrm{BA}$ & $14.21 \mathrm{bc}$ & $14.13 b$ & $14.28 \mathrm{bc}$ & $14.09 \mathrm{~b}$ \\
\hline $1 \mu \mathrm{l} / \mathrm{L} 1-\mathrm{MCP} \times 150 \mathrm{ppm} \mathrm{BA}$ & $14.67 \mathrm{~b}$ & $14.56 \mathrm{ab}$ & $14.94 \mathrm{~b}$ & $14.41 b$ \\
\hline $2 \mu \mathrm{l} / \mathrm{L} 1-\mathrm{MCP} \times 150 \mathrm{ppm} \mathrm{BA}$ & $15.86 \mathrm{a}$ & $15.18 \mathrm{a}$ & $16.13 \mathrm{a}$ & $15.36 \mathrm{a}$ \\
\hline
\end{tabular}

Numbers followed by the same letter $(\mathrm{s})$ are not significantly different $(\mathrm{P}<0.05)$.

Vase life

The mean comparison table of BA and 1-MCP interactive effects on the vase life suggested that the longest vase life was obtained from the application of $150(\mathrm{ppm}) \mathrm{BA}+2$ ( $\mu \mathrm{l} . \mathrm{L}) 1-\mathrm{MCP}$ with an average of 12.81 days and shortest from the control treatment with an average of 8.04 days. The results indicated that $\mathrm{BA}$ was more effective than 1-MCP on vase life. Ethylene content was diminished by the increase in BA concentration and consequently, the vase life was enhanced. But the best result was obtained when BA and 1MCP were used together at the highest concentrations. Both of these anti-aging substances disturb ethylene functioning by the competitive inhibition method, which resulted in the vase life prolongation. The increased viability and vase life of the cut flowers might be due to the increase in carbohydrate content in the treatment (Argueso et al., 2009). 1-MCP maintained the plants' leaves (cut flowers) in a good condition and prevented the reduction of their dry weight by lowering the percentage of weight loss and inhibition of chlorophyll and carbohydrates damage (Serek et al., 2014) which extended their vase life. The experiments results demonstrated that in the control treatment, the vase life was decreased by 37 percent compared to the 150 $(\mathrm{ppm}) \mathrm{BA}+2$ ( $\mu \mathrm{l} . \mathrm{L})$ 1-MCP treatment (Figure 1). Water uptake was higher in the flowers treated with 1MCP compared to the control. Hence this factor might have played an important role in vase life improvement (Paull and Goo, 2005).

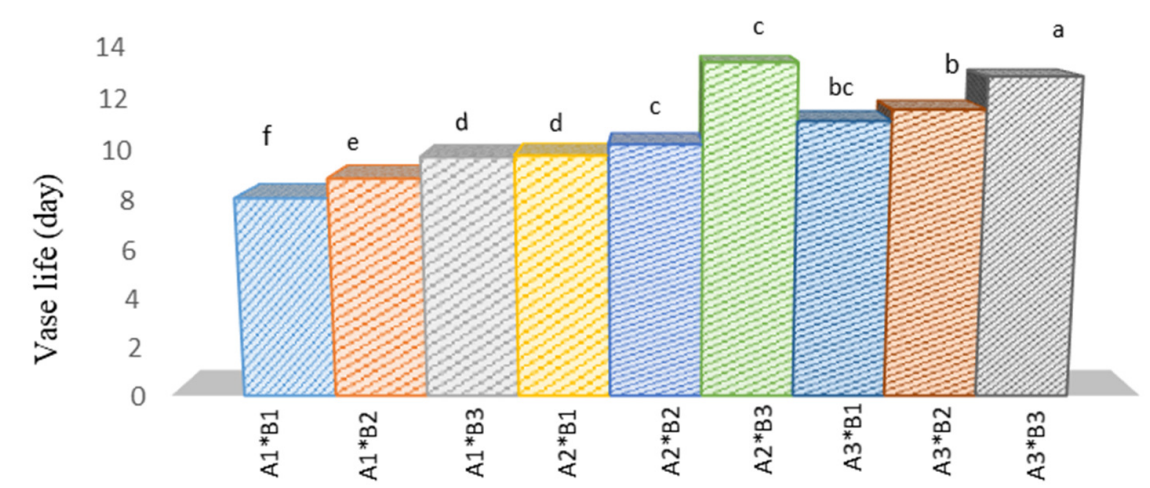

Figure 1. The interaction of BA and 1-MCP on vase life; A1 (0 ppm BA), A2 (75 ppm BA), A3 (150 ppm BA), B1 (0 $\left.\mu 1 . L^{-1} 1-\mathrm{MCP}\right), \mathrm{B} 2\left(1 \mu \mathrm{l} . \mathrm{L}^{-1} 1-\mathrm{MCP}\right), \mathrm{B} 3\left(2 \mu \mathrm{l} . \mathrm{L}^{-1} 1-\mathrm{MCP}\right)$

\section{Ethylene}

The results of the analysis of variance showed that ethylene was affected by simple and interactive effects of BA and 1-MCP on different days (Table 11). The results of the means comparison showed that on 
the second day, the highest amount of ethylene was observed in the control treatment with an average of $2.431 \mathrm{nl} / \mathrm{gFW} . \mathrm{h}$ and the lowest was related to $150 \mathrm{ppm} \mathrm{BA}+2 \mu \mathrm{l} \cdot \mathrm{L}^{-1} 1-\mathrm{MCP}$ with an average of 1.602 $\mathrm{nl} / \mathrm{gFW} . \mathrm{h}$ (Table 12). According to the results in Table 12, the highest ethylene content was observed in the control treatment with an average of $2.628 \mathrm{nl} / \mathrm{g} \mathrm{FW}$.h on the fourth day and the lowest was obtained from the treatment of $150 \mathrm{ppm} \mathrm{BA}+2 \mu \mathrm{l} . \mathrm{l}^{-1} 1-\mathrm{MCP}$ (an average of $1.871 \mathrm{nl} / \mathrm{g} \mathrm{FW} . \mathrm{h}$.) (Table 12). Although the concentration of BA and 1-MCP significantly reduced the petal aging process, the amount of ethylene was increased significantly by day 8 , which was the beginning of the cell aging process. The results showed that the lowest ethylene level was observed on day 8 , from $150 \mathrm{ppm} \mathrm{BA}+2 \mu \mathrm{l} . \mathrm{L}^{-1} 1-\mathrm{MCP}$ with an average of 2.021 $\mathrm{gl} / \mathrm{g} \mathrm{FW} . \mathrm{h}$. and the highest ethylene content was observed in the control treatment with an average of 2.963 nl/g FW.h.).

Table 11. Analysis of variance of ethylene under BA and 1- MCP

\begin{tabular}{|c|c|c|c|c|c|}
\hline & & & M.s & & \\
\hline S.O.V & df & Day2 & Day4 & Day6 & Day8 \\
\hline BA & 2 & $0.0041^{*}$ & $0.742^{*}$ & $0.051^{*}$ & $0.281^{*}$ \\
\hline $1-\mathrm{MCP}$ & 2 & $0.0037^{*}$ & $0.829^{*}$ & $0.045^{*}$ & $0.315^{*}$ \\
\hline $1-\mathrm{MCP} \times$ BA & 4 & $2.215^{* *}$ & $125.412^{* *}$ & $0.048^{*}$ & $0.287^{*}$ \\
\hline Error & 27 & 0.0005 & $0 / 12$ & 0.007 & 0.41 \\
\hline CV & - & 6.04 & 5.86 & 7.41 & 6.94 \\
\hline
\end{tabular}

${ }^{\mathrm{ns}},{ }^{* *}$ and ${ }^{*}$ represent non-significant and significant at the $1 \%$ and $5 \%$ probability levels, respectively.

The aging of flowers is accompanied by many physiological and biochemical changes. In rose flowers, when the flowers are in the bud stage, they produce little ethylene, but gradually ethylene production increases as the petals open, and in fully open flowers, the amount of ethylene reaches its maximum (Sood et al., 2006).

The effect of cytokines has been shown, is delay aging due to changes in the ethylene signaling pathway. Exogenous cytokinin concentrations in the petals of carnation changed their sensitivity to ethylene as well as their endogenous ethylene production (Chang et al., 2005). Other studies are well characterized by ethylene and cytokinin during the aging process in petals, which shows that ethylene accelerates the process of cytokinin degradation, thereby accelerating the aging process (Taverner et al., 1999).

Table 12. Comparison of interactions between BA and 1- MCP for ethylene

\begin{tabular}{|c|c|c|c|c|}
\hline & \multicolumn{4}{|c|}{ Soluble carbohydrate $(\mathrm{mg} / \mathrm{g})$} \\
\hline Treatments & Day 2 & Day 4 & Day 6 & Day 8 \\
\hline Control & $2.431 \mathrm{a}$ & $2.628 \mathrm{a}$ & $2.785 \mathrm{a}$ & $2.963 \mathrm{a}$ \\
\hline $1 \mu \mathrm{l} / \mathrm{L} 1-\mathrm{MCP}$ & $2.284 \mathrm{~b}$ & $2.481 \mathrm{~b}$ & $2.604 \mathrm{a}$ & $2.741 \mathrm{a}$ \\
\hline $2 \mu \mathrm{l} / \mathrm{L} 1-\mathrm{MCP}$ & $2.197 \mathrm{bc}$ & $2.372 \mathrm{bc}$ & $2.532 \mathrm{ab}$ & $2.611 \mathrm{ab}$ \\
\hline $75 \mathrm{ppm} \mathrm{BA}$ & $2.253 \mathrm{bc}$ & $2.486 \mathrm{~b}$ & $2.584 \mathrm{ab}$ & $2.658 \mathrm{ab}$ \\
\hline $1 \mu \mathrm{l} / \mathrm{L} 1-\mathrm{MCP} \times 75 p p m$ BA & $2.218 \mathrm{bc}$ & $2.041 \mathrm{~cd}$ & $2.192 \mathrm{bc}$ & $2.394 \mathrm{bc}$ \\
\hline $2 \mu \mathrm{l} / \mathrm{L} 1-\mathrm{MCP} \times 75 \mathrm{ppm} \mathrm{BA}$ & $2.145 \mathrm{c}$ & $1.928 \mathrm{de}$ & $2.011 \mathrm{c}$ & $2.186 \mathrm{c}$ \\
\hline $150 \mathrm{ppm} \mathrm{BA}$ & $2.143 \mathrm{c}$ & $2.186 \mathrm{c}$ & $2.304 \mathrm{abc}$ & $2.438 \mathrm{~b}$ \\
\hline $1 \mu \mathrm{l} / \mathrm{L} 1-\mathrm{MCP} \times 150 \mathrm{ppm} \mathrm{BA}$ & $1.741 \mathrm{~d}$ & $1.819 \mathrm{cde}$ & $2.054 \mathrm{bc}$ & $2.241 \mathrm{bc}$ \\
\hline $2 \mu \mathrm{l} / \mathrm{L} 1-\mathrm{MCP} \times 150 \mathrm{ppm} \mathrm{BA}$ & $1.602 \mathrm{~d}$ & $1.871 \mathrm{e}$ & $1.987 \mathrm{c}$ & $2.021 \mathrm{c}$ \\
\hline
\end{tabular}

Numbers followed by the same letter $(s)$ are not significantly different $(\mathrm{P}<0.05)$.

Although ethylene was increased in the present study from the second day, due to the effect of 1-MCP, the vase life of the cut flowers was increased. The positive effects of 1-MCP on reducing the harmful effects of ethylene on rose, gerbera, and orchid plants were also reported (Song et al., 2014). It was also found that the 
effect of cytokinins in delaying aging is due to alterations in the ethylene signaling pathway (Chang et al., 2005).

\section{Conclusions}

In this study, it was found that BA preserved the structure of proteins by delaying the degradation of degraded nitrogenous compounds that play an important role in protein structure. The aging of flowers is accompanied by many physiological and biochemical changes. The interaction of BA and 1-MCP on the 8th day showed that without anti-aging substances, the treatments produced the highest amount of ethylene. Flowers treated with 1-MCP had higher water uptake than the control. By protecting proteins by reacting with phospholipids, proline stabilizes cell membranes and acts as a purifier of active species of energy storage and nitrogen source. BA, together with water retention, reduced endoprotease activity and inhibited protein degradation, thus prolonging postharvest longevity in roses. Our results showed that ethylene decreased as the concentration of BA was increased, and the vase life of cut roses was increased. But the best results were obtained when BA and 1-MCP were used in combination with the highest concentration, both of which inhibit ethylene work by competitive inhibition and increase flower vase life.

\section{Authors' Contributions}

All authors read and approved the final manuscript

\section{Acknowledgements}

The authors gratefully acknowledge the research department of Islamic Azad university of Arak branch for supporting the current research.

This research received no specific grant from any funding agency in the public, commercial, or not-forprofit sectors.

\section{Conflict of Interests}

The authors declare that there are no conflicts of interest related to this article.

\section{References}

Anonymous (2016). The biology and ecology of Rosa x Hybrida (Rose). Department of Health and Ageing Office of the Gene Technology Regulator.

Argueso CT, Ferreira FJ, Kieber JJ (2009). Environmental perception avenues: the interaction of cytokinin and environmental response pathways. Plant Cell Environmental 32:1147-1160. https://doi.org/10.1111/j.13653040.2009.01940.x

Ashraf M, Foolad M (2007). Roles of glycine betaine and proline in improving plant abiotic stress resistance. Environmental and Experimental Botany 59:206-216. https://doi.org/10.1016/j.envexpbot.2005.12.006

Bates LS, Waldren RP, and Teare ID (1973). Rapid determination of free proline for water stress studies. Plant and Soil 312:475-479.

Buchanan-Wollaston V (2015). The molecular biology of leaf senescence. Journal of Experimental Botany 135:11011109. https://doi.org/10.1093/jxb/48.2.181 
Chang H, Jones ML, Banowetz GM, Clark DG (2005). Overproduction of cytokinins in petunia flowers transformed with PSAG12-IPT delays corolla senescence and decreases sensitivity to ethylene. Plant Physiology132:2174218. https://doi.org/10.1104/pp.103.023945

Chutichudet P, Chutichudet B, M.Boontiang K (2010). Effect of 1-MCP fumigation on vase life and other postharvest qualities of siam tulip (Curcuma aeruginosa Roxb.) cv. Laddawan. International Journal of Agricultural Research 5(1):1-10. https://doi.org/10.3923/ijar.2010.1.10

Darras A, Akoumianaki-Ioannidou A, Pompodakis EN (2010). Evaluation and improvement of post-harvest performance of cut Viburnum tinus inflorescence. Scientia Horticulturae 124(3):376380. https://doi.org/10.1016/j.scienta.2010.01.018

Eason JR, Ryan DJ, Pinkney TT, and O'Donoghue EM (2002). Programmed cell death during flower senescence: Isolation and characterization of cysteine proteinases from Sandersonia aurantiaca. Functional Plant Biology 29(9):1055-1064. https://doi.org/10.1071/PP01174

Hahn EJ, Jeon MW, and Paek KY (2011). Culture method and growing medium affect growth and flower quality of several gerbera cultivars. Acta Horticulturae 589:385-392. https://doi.org/10.17660/ActaHortic.2001.548.44

Huang KL, Liao LJ, Shen RS, Chen WS, and Lin YH (2009). The -synergetic effect of maleic hydrazide (1.2-dihydro3,6-pyridazinedione) and sucrose on vase life of cut roses. Australian Journal of Experimental Agriculture 42:637-641. https://doi.org/10.1071/EA01101

Humaid A (2004). Silver thiosulphate prolongs vase life and improves quality of cut gladiolusand rose flowers. Journal of Food Agriculture and Environment 2(2):269-300. https://doi.org/10.1234/4.2004.213

Ichimura K, Shimizu H, Iraya T, and Hisamatsu T (2015). Effect of 1-methylcyclopropene (1-MCP) on the vase life of cut carnation, Delphinium and sweet pea flowers. Bulletin of the National Institute for the Flora Science 2:1-8.

Iqbal D, Habib U, Abbasi NA, and Chaudhry AN (2012). Improvement in postharvest attributes of Zinnia (Zinnia elegans cv. Benarys Giant) cut flowers by the application of various growth regulators. Pakistan Journal of Botany 44:1091-1094.

Irigoyen JJ, Emerich DW, and Sanchez Diz, M (1993). Water stress induced changes in concentrations of proline and total soluble sugars in modulated of alfalfa (Medicago sativa). Physiologia plantarum 84(1):55.60. https://doi.org/10.1111/j.1399-3054.1992.tb08764.x

Jin J, Ningwei SH, Nan M, Jinhe B, and Junping C (2016). Regulation of ascorbate peroxidase at the transcript level is involved in tolerance to post harvest water deficit stress in the cut rose cv. Samantha. Postharvest Biology and Technology 82:206-213. https://doi.org/10.1016/j.postharvbio.2006.01.014

Kader AA (2013). Postharvest technology of horticultural crops - An Overview from farm to fork. Ethiopian Journal of Science and Technology 1:1-8.

Kumar N, Srivastava GC, Dixit K (2008). Role of sucrose synthase and invertases during petal senescence in rose (Rosa hybrida L.). The Journal of Horticultural Science and Biotechnology 83:520-524. https://doi.org/10.1080/14620316.2008.11512416

Liao LJ, Huang KL, Chen WS, and Cheng YM (2009). Postharvest life of cut rose flowers as affected by silver thiosulfate and sucrose. Botanical Bulletin - Academia Sinica Taipei 41(4):299-303.

Macnish Aj, Leonard RT, Borda AM, Nell T (2010). Genotypic variation in the postharvest performance and ethylene sensitivity of cut rose flowers. HortScience 45(5):790-796. https://doi.org/10.21273/HORTSCI.45.5.790

Mutu TM (2011). Effect of Accel on the vase life and postharvest quality of Rosa spp. cut flowers. American Journal Science Technology 36:96-99.

Ozden M, and Karaaslan M (2011). Effects of cytokinin on callus proliferation associated with physiological and biochemical changes in Vitis vinifera L. Acta Physiologiae Plantarum 33(4):1451-1459. https://doi.org/10.1007/s11738-010-0681-9

Paull RE, and Goo T (2005). Ethylene and water stress in the senescence of cut rose flowers. Journal of the American Society for Horticultural Science 110:84-88.

Rao SR, Qayyum A, Razzaq A, Ahmad M, Mahmood I, and Sher A (2012). Role of foliar application of salicylic acid and L-tryptophan in drought tolerance of maize. Journal of Animal and Plant Sciences 22:768-772.

Ranwala AP, and Miller WB (2000). Preventive mechanisms of gibberellin ${ }_{4+7}$ and light on low-temperature-induced leaf senescence in Lilium cv. Stargazer. Postharvest Biology and Technology 19:85-92. https://doi.org/10.1016/S0925-5214(00)00072-7 
Sahi BG (2009). Effect of cycocel spray and BA on the growth and flowering of Rosa hybrida. Coolwater. LN Duhok Journal University 12:39-43.

Serek M, Sisler EC, and Reid MS (2014). 1-methylcyclopropene, a novel gaseous inhibitor of ethylene action, improves the life of fruits, cut flowers and potted plants. Acta Horticulturae 596:887-892. https://doi.org/10.17660/ActaHortic.1995.394.37

Sisler EC, Serek M, and Dupille E (2009). Comparison of cyclopropene, 1-methylcyclopropene, and 3, 3dimethylcyclopropene as ethylene antagonists in plants. Plant Growth Regulation 18:164-174. https://doi.org/10.1007/BF00024378

Song J, Fan L, Hughes T, Palmer Campbell L, Li L, Li XH (2014). Quantitative proteomic investigation on the effect of 1-methylcyclopropene treatments on postharvest quality of selected cut flowers. In XXIX International Horticultural Congress on Horticulture: Sustaining Lives, Livelihoods and Landscapes (IHC2014) 1104:311318. https://doi.org/10.17660/ActaHortic.2015.1104.47

Sood SH, Vyas D, Nagar PK (2006). Physiological and biochemical studies during flower development in two rose species. Sicentia Horticulturae 108:390-396. https://doi.org/10.1016/j.scienta.2006.02.012

Taverner E, Letham DS, Wang J, Cornish E, Willcocks D (1999). Influence of ethylene on cytokinin metabolism in relation to Petunia corolla senescence. Phytochemistry 51:341-347. https://doi.org/10.1016/S00319422(98)00757-2

Van Meeteren U, Van Gelder H, Van Ieperen W (1999). Reconsideration of the use of deionized water as vase water in postharvest experiments on cut flowers. Postharvest Biology and Technology 17(3):139-141.

Wagstaff C, Leverentz MK, Griffiths G, Thomas B, Chanasut U, Stead AD, and Rogers HJ (2002). Cysteine protease gene expression and proteolytic activity during senescence of Alstroemeria petals. Journal of Experimental Botany 53:233-240. https://doi.org/10.1093/jexbot/53.367.233

Wang YT (2009). Cytokinin and light intensity regulate flowering of Easter Lily. Horticultural Since 98:432-436.

Yamada A, Sekiguchi M, Mimura T, Ozeki Y (2012). The role of plant CCT $\boldsymbol{\alpha}$ in salt- and osmotic-stress tolerance. Plant and Cell Physiology 43:1043-1048. https://doi.org/10.1093/pcp/pcf120

Yang CW, Kao CH (2000). Ammonium in relation to proline accumulation in detached rice leaves. Plant Growth Regulation 30:139-144. https://doi.org/10.1023/A:1006329919243
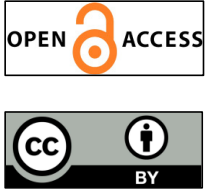

The journal offers free, immediate, and unrestricted access to peer-reviewed research and scholarly work. Users are allowed to read, download, copy, distribute, print, search, or link to the full texts of the articles, or use them for any other lawful purpose, without asking prior permission from the publisher or the author.

License - Articles published in Notulae Botanicae Horti Agrobotanici Cluj-Napoca are Open-Access, distributed under the terms and conditions of the Creative Commons Attribution (CC BY 4.0) License. (c) Articles by the authors; UASVM, Cluj-Napoca, Romania. The journal allows the author(s) to hold the copyright/to retain publishing rights without restriction. 